\title{
Growth of cut roses under application of products with physiological effects
}

\author{
Higor Mcarter Senra Almeida', João Henrique Ferreira Sabino², \\ Maria de Lourdes Neres da Silva², Victoria Jéssica Galvão de Freitas², \\ Anamaria Ribeiro Pereira Ramos², Márkilla Zunete Beckmann-Cavalcante ${ }^{2}$ \\ 'Federal University of Piaui, Brazil \\ ${ }^{2}$ Federal University of São Francisco Valley, Brazil \\ *Corresponding author, e-mail: markilla.beckmann@univasf.edu.br
}

\begin{abstract}
The cultivation of cut roses can be compromised when cultivated in regions where climatic conditions are limiting for their adequate growth and development, so it is necessary to use appropriate technologies and inputs for their production. The application of products that promote physiological changes in the plant, such as fungicides or plant regulators might be viable technologies for rose production. The objective of this study was to evaluate the growth of $\mathrm{cv}$. Carola under application of products with physiological effects cultivated in the Valley of the submedium São Francisco. The experimental design was a randomized complete block design in a $6 \times 6$ factorial design, with 6 products with physiological action (control - application of water, boscalid, pyraclostrobin, boscalid + pyraclostrobin, fluxapyroxad + pyraclostrobin and plant growth regulator) and 6 periods of analysis $(40,68,124,180,236$ and 292 days after transplantation, DAT) with four replicas of 12 plants each. Throughout the dates were evaluated the number of leaves, leaf area, total leaf chlorophyll, dry mass of leaves, stems, flowering branches, total dry mass, production of stems per plant and the biomass partition. There were significant differences for all variables studied except for the production of stems per plant. Regarding the biomass partition, a variation of values among applied products was observed over time, however, fluxapyroxad + pyraclostrobin and the growth regulator presented a balance among the dry mass of leaves, stem and flowering branches. The application of products belonging to the group of strobilurins as well as growth regulators is promising for the cultivation of cut roses in the semiarid.
\end{abstract}

Keywords: Rosa sp.; floriculture; fungicides; growth analysis

\section{Introduction}

Among the traditionally produced and consolidated ornamental plants in the national and international market, the roses stand out. The rose has always been among the three most wanted ornamental species, occupying a special place among the cut flowers commercialized in Brazil. It is estimated that more than 320 million stems of roses were commercialized in 2014 , representing a $10 \%$ growth over the traded value in the previous year (Rigueira, 2015).

To reach a high rentability, the productive system in roses is highly influenced by the cultural handling and climate conditions (Greyvenstein et al., 2014). The ideal temperature for their full development must be within a range of 16 to $28^{\circ} \mathrm{C}$, in which the daytime recommended temperature lies within 23 to $25^{\circ} \mathrm{C}$, and the nocturnal recommended temperature within 15 to $18^{\circ} \mathrm{C}$ (Barbosa et al., 2005). In this context, the choice of the region becomes a limiting factor and requires the usage of cultivation techniques that may allow the development of the crop. The usage of a protected environment might be an alternative for the controlling of climate conditions (Barbosa et al., 2005) allied to the usage of other inputs, such as products which actuate in the physiology and the metabolism of the plants (Hashemabadi \& Zarchin, 2010). 
The application of products which actuate in the plant development and cause a physiological effect, aiding in the growth of the plants, such as some fungicides and vegetal regulators might be a viable technology to rose production in the northeastern semiarid. According to Ramos et al. (2015), these products, aside proportioning improvements in the quantity and quality of the production, might also favor the final product, with an influence in the postharvest quality.

During the last research decades on the fungicide properties of the strobilurins, for example, direct influences in physiological processes of plants were proved independently of disease control, such as the increase in photosynthetic efficiency, greener leaves and higher chlorophyll index, in the activity of the nitrate reductase enzyme and of a range of antioxidating enzymes, resulting in a better vegetal development and, consequently, a higher productivity (Bartlett et al., 2001; Kanungo \& Joshi, 2014).

The pyraclostrobin, a fungicide of the strobilurins group, also indicated in the control of rose plants diseases, has also shown advantages due to its positive physiological action over cultivated plants (Kanugo \& Joshi, 2014). With a similar action to the strobilurins, there is the fluxapyroxad molecule, within the chemical group of the carboxamides (Avenot \& Michailides, 2010) and the boscalid fungicide (chemical group of the anilides) (Sirtoli et al., 2011; Colombari et al., 2015).

The usage of vegetal regulators or their mixtures also present effects over the metabolism of the plant and, with a similar action to the vegetal hormones, it appears as an alternative in rose production, since they are associated with vegetal growth, causing physiological and structural modifications which might result in a yield increment (Hashemabadi \& Zarchini, 2010; Santos et al., 2012).

Given the absence of reports on the usage of fungicides which promote physiological alterations on rose crop and, assuming that they can positively influence in the physiological development of the vegetal, in the control and stresses decrease, reducing the metabolic activity and promoting gains in the quality of the final product, we aimed to verify the influence of products with physiological effects and vegetal regulators on the growth of cut rose cv. Carola, cultivated in the submedium São Francisco valley.

\section{Material and methods}

The experiment was conducted in a shade house (50\% shadowing) in the Floriculture Sector of the Federal University of the São Francisco Valley (UNIVASF), situated in the municipality of Petrolina, State of Pernambuco (geographical coordinates $09^{\circ} 21^{\prime} \mathrm{S}, 40^{\circ} 34^{\prime} \mathrm{W}$ ). According with Köppen classification, the region is classified as "BSh" (dry climate, semiarid with low latitude and altitude), annual pluviosity inferior to $500 \mathrm{~mm}$ distributed in the months between November and April (Alvares et al., 2014).

The soil of the area was classified as Orthic Quartzarenic Neosol (Embrapa, 2013). The data concerning temperature and relative humidity were obtained through $\mathrm{HOBO}$ U12-012 Temp/RH/Light/External Data Logger equipments installed in the interior of the shade house at $2,0 \mathrm{~m}$ over the soil surface. The precipitation data were obtained from the meteorological station installed at approximately $500 \mathrm{~m}$ from the experiment (Figure 1).

The experimental design utilized was in randomized blocks in a factorial scheme of $6 \mathrm{X}$ 6 , with 6 products with physiological action ( $\mathrm{T} 1$ : control - application of water); T2: boscalid; T3: pyraclostrobin; T4: mixture of boscalid + pyraclostrobin; T5: fluxapyroxad + pyraclostrobin and T6: vegetal regulator) and 6 periods of growth analysis $(40,68,124,180,236$ and 292 days after transplantation, DAT) with four repetitions. Each repetition was composed by 12 plants (ten useful plants and two utilized as surrounding).

Sixty days before the transplant of the seedlings the chemical analysis of the soil was performed (Table 1), and also the preparing of the grooves applying tanned cattle manure. For the ground fertilization an amount of $48 \mathrm{~kg} \mathrm{ha}^{-1}$ of NPK 6-24-12 was applied, according to the recommendation for the State of Pernambuco (Cavalcanti, 2008). 

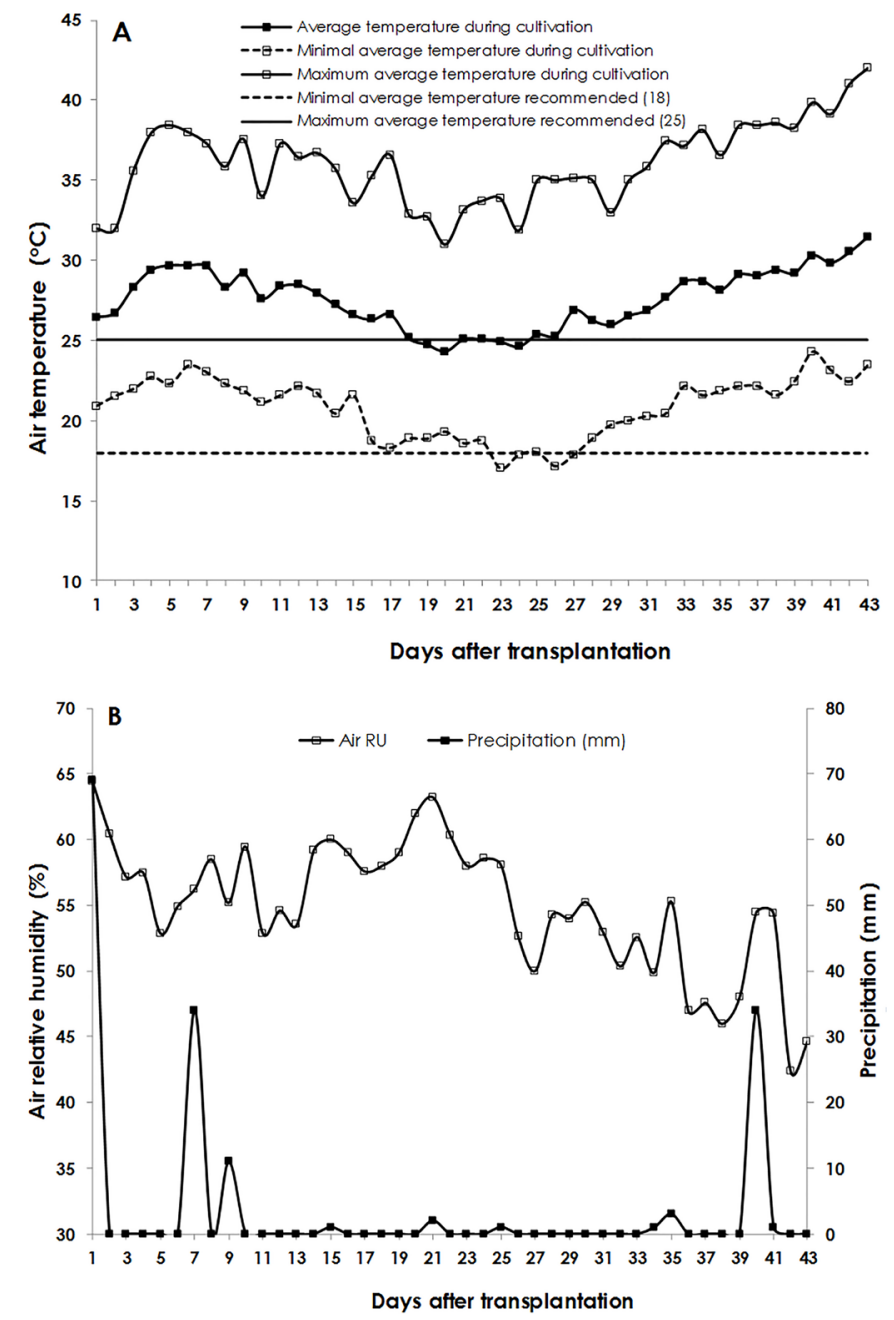

Figure 1. Air temperature (A), air relative humidity and precipitation (B) during the experimental period. Petrolina-PE, 2016. Obs.: Minimal and maximum average temperatures recommended by Barbosa et al. (2005).

Table 1. Chemical analysis of the soil in the experimental area for the cultivation of cut rose cv. Carola.

\begin{tabular}{|c|c|c|c|c|c|c|c|c|c|c|c|c|}
\hline Depth & $\begin{array}{c}\mathrm{pH} \\
\mathrm{H}_{2} \mathrm{O} \quad 1: 2.5\end{array}$ & $\mathrm{Ca}^{2+}$ & $\mathrm{Mg}^{2+}$ & $\mathrm{Na}^{+}$ & $\mathrm{K}^{+}$ & $\begin{array}{c}S B \\
m o l \\
m o\end{array}$ & $\mathrm{H}+\mathrm{Al}$ & T & $\mathrm{Al}^{3+}$ & $\begin{array}{l}V \\
\% \\
\end{array}$ & $\begin{array}{c}P \\
m g d m^{-3}\end{array}$ & $\begin{array}{c}\text { M.O. } \\
\%\end{array}$ \\
\hline $0-20 \mathrm{~cm}$ & 6.1 & 3.5 & 1.0 & 0.02 & 0.29 & 4.81 & 1.32 & 6.13 & 0.00 & 78.46 & 5.09 & 2.04 \\
\hline $20-40 \mathrm{~cm}$ & 5.5 & 2.3 & 0.7 & 0.03 & 0.29 & 3.32 & 2.15 & 5.47 & 0.00 & 60.77 & 2.65 & 1.45 \\
\hline
\end{tabular}

For the experiment, seedlings of rose cultivar "Carola" were utilized, with red color, propagated through cuttings, acquired from commercial producer and certified. The cultivation was performed on 12 February and conducted until December 10, 2016. The experiment was conducted during the vegetative phase of the crop, extending until the beginning of the production period.

The planting was performed in simple lines with $1.0 \mathrm{~m}$ spacing between lines and 0,25 $\mathrm{m}$ between plants. An irrigation system through dripping was utilized, with self-compensating drippers (one emitter per plant with nominal flow rate of $3.3 \mathrm{~L} \mathrm{~h}^{-1}$ and distribution uniformity coefficient of $93 \%$ ). The fertigation of the roses was performed through an injector of the Venturi type, with the application of $2.3 \mathrm{~kg}$ of calcium nitrate, dissolved in $15 \mathrm{~L}$ of water, and through foliar via, each 15 days, with the application of $40 \mathrm{~mL}$ of Mastermins ${ }^{\circledR}\left(14 \% \mathrm{~N}, 4 \% \mathrm{P}_{2} \mathrm{O}_{5}, 6 \% \mathrm{~K}_{2} \mathrm{O}\right.$, $2 \% \mathrm{Zn}, 1.5 \% \mathrm{Mn}, 0.1 \% \mathrm{~B}$ and $0,05 \% \mathrm{Mo}$ ) and $10 \mathrm{~mL}$ of Natur'IÓleo ${ }^{\circledR}$ adjuvant (vegetal oil: $93,0 \%$ v/v; inert ingredients: $7,0 \% \mathrm{v} / \mathrm{v}$ ) in $20 \mathrm{~L}$ of water.

During the experimental period the inherent cultivation practices were performed, such as formation prunings $(69,125$ and 185 days after transplantation DAT); sprout thinnings and 
buds removal; tutoring of the plants; control of weeds through manual hoeing and monitoring of plagues and diseases. The plagues identified in the crop were: aphids (Macrosiphum sp), thrips (Frankliniella $\mathrm{sp}$ ) and the silverleaf whitefly (Bemisia tabaci). The disease found during the development and growth of the roses was the powdery mildew (Oidium leucoconium). The control was performed with the pulverization of sulfur, Eforia + Natural oleum ( $15 \mathrm{~mL} 20 \mathrm{~L}^{-1}$ water), Pirate + Natural oleum $\left(10 \mathrm{~mL}+10 \mathrm{~mL}+20 \mathrm{~L}^{-1}\right.$ water), Piretron + Natural oleum (45 mL $\left.20 \mathrm{~L}^{-1}\right)$,
Auge (4 mL $20 \mathrm{~L}^{-1}$ water) e Kali Green (100g + 20 $L^{-1}$ water).

The first application of treatments (Table 2) was performed at 41 days after the transplantation of the seedlings, when they were stablished, and the remaining applications occurred at each 15 days during the whole experimental period. An amount of $0.5 \%$ of vegetal oil was added, aiming the protection against losses through evaporation, drift or washing, and the usage of plastic curtains to avoid drift between treatments.

Table 2. Products with physiological action applied during the growth of cut rose cv. Carola.

\begin{tabular}{|c|c|c|c|c|c|}
\hline Treatments & $\begin{array}{c}\text { Active ingredient/ } \\
\text { Composition }\end{array}$ & Chemical Group* (Class**) & Commercial Name & $\begin{array}{c}\text { Concentration } \\
\text { (g i.a./L or g/Kg) }\end{array}$ & Dosage \\
\hline $\mathrm{Tl}$ & $\begin{array}{l}\text { Control } \\
\text { (water) }\end{array}$ & - & - & (1) & - \\
\hline$T 2$ & Boscalid & Anilid (F) & Cantus $\AA$ & $500 \mathrm{~g} / \mathrm{kg}$ & $0.15 \mathrm{~g} / \mathrm{L}$ \\
\hline T3 & Pyraclostrobin & Strobilurin (F) & Comet@ & $250 \mathrm{~g} / \mathrm{L}$ & $0.80 \mathrm{~mL} / \mathrm{L}$ \\
\hline T4 & $\begin{array}{l}\text { Mixture of: } \\
\text { Boscalid and } \\
\text { Pyraclostrobin }\end{array}$ & Anilid and Strobilurin (F) & Cantus $\AA$ e Comet $\AA$ & $\begin{array}{c}500 \mathrm{~g} / \mathrm{kg} \mathrm{e} \\
250 \mathrm{~g} / \mathrm{L}\end{array}$ & $\begin{array}{c}0.15 \mathrm{~g} / \mathrm{L} \\
\text { e } 0.80 \mathrm{~mL} / \mathrm{L}\end{array}$ \\
\hline T5 & $\begin{array}{l}\text { Ready mixture: } \\
\text { Fluxapyroxad + } \\
\text { Pyraclostrobin }\end{array}$ & Carboxamide + Strobilurin(F) & Orkestra® SC & $167+333 \mathrm{~g} / \mathrm{L}$ & $2.5 \mathrm{~mL} / \mathrm{L}$ \\
\hline T6 & $\begin{array}{l}\text { Ready mixture: } \\
\text { Kinetin + Gibberellic } \\
\text { acid + 4-indol-3- } \\
\text { ylbutyric acid }\end{array}$ & $\begin{array}{l}\text { Cytokinin + Gibberellin + } \\
\text { Indolalcanoic acid(VR) }\end{array}$ & Stimulate ${ }^{\circledR}$ & $\begin{array}{c}0.09 \mathrm{~g} / \mathrm{L}+0.05 \mathrm{~g} / \mathrm{L} \\
+0.05 \mathrm{~g} / \mathrm{L}\end{array}$ & $1 \mathrm{ml} / \mathrm{L}$ \\
\hline
\end{tabular}

Six evaluations were performed for the obtaining of the primary data on the growth of the plants. The first evaluation occurred at 40 days after transplantation (DAT) of the seedlings (one day before the application of the treatments), and the remaining at 68, 124, 180, 236 and 292 DAT. The evaluated variables were: number of leaves, counting of all leaves on the plant; shoot area $(\mathrm{cm} 2)$, obtained with a shoot area bench-meter (Li-Corß, model LI-3100); dry mass of leaves, stems, flowering branches and total dry mass, with different organs placed in paper bags and transferred for drying in drying oven with forced air circulation at $70^{\circ} \mathrm{C}$ until reaching constant mass, with later weighing in precision balance 0,01g (Sartorious $\AA$ ) and Total foliar chlorophyll (TFC) content with the aid of a chlorophyll meter (Falker®, Brasil).

The stems collection began at 264 DAT, when $50 \%$ of the plants presented commercial harvesting stems, considering this epoch as the adult phase, according to the stablished by
Oliveira et al. (2014). In this perspective, until 292 DAT the sum of collections of commercial stems was performed and the production concerning the number of stems per plant was presented. These data were analyzed in randomized blocks comparing the six treatments concerning the products with physiological action.

The data were subjected to variance analysis for diagnosis of the significative effect through the $\mathrm{F}$ test at $5 \%(\mathrm{P}<0.05)$ probability and averages comparison through the ScottKnott test. The assimilates partitioning through the development of the plants was obtained with the transformation of the primary data on mass allocation for each organ to percentage. The number of leaves was transformed utilizing $\sqrt{ } x+0.5$. All analysis were performed with the aid of the statistical software ASSISTAT 7.7 beta (Silva \& Azevedo, 2016).

\section{Results and Discussion}

Considering the presented results, it was observed that there was no statistical difference 
among applied products for the number of leaves, foliar area and total chlorophyll. However, for these variables, there was statistical difference throughout time. For the number of leaves a significative effect occurred for the interaction of the applied products $x$ DAT (Table 3 ).

At observing the interaction effect for the number of leaves (Table 4) it was observed that there was no significative effect among applied products in none of the evaluations performed. There was only effect of time over this variable, with a higher number of leaves in the last evaluation, which is normal due to the development of the plants. It is worth noting that the first pruning was performed at 69 DAT and T3 was the only treatment which kept the number of leaves statistically equal from 40 to 124 DAT, occurring a significative difference only from 180 DAT and being statistically equal to 236 DAT.
It was observed that T3, treatment composed only by the pyraclostrobin molecule, started to have an effect on a later time (180 DAT), whilst T2, which was the treatment with the mixture of boscalid and pyraclostrobin showed an increment in the number of leaves from 124 DAT; and, in advance, at 68 DAT, previously to the first pruning, 15 , whose product is originally the mixture of fluxapyroxad + pyraclostrobin, showed an increment in the number of leaves, resulting in a superior significative difference compared to 40 DAT (Table 4).

The initial lower number of leaves is due to the fact that the plants were in the beginning of the acclimatization process of the new seedlings to the new environment and throughout time, due to the development and plant growth the number of leaves was consequently increased, stabilizing after the second pruning (125 DAT)

Table 3. Number of leaves (NL), foliar area (FA) e total foliar chlorophyll (CloT) of rose cv. Carola under application of different products with physiological action at 40,68, 124, 180, 236 and 292 days after transplantation of the seedlings (DAT).

\begin{tabular}{|c|c|c|c|}
\hline \multirow{2}{*}{ Variation cause } & $N L^{(a)}$ & FA & Clot \\
\hline & - & $\mathrm{cm}^{2}$ & ICF \\
\hline Products (P) ("F") & $0.74^{\mathrm{ns}}$ & $1.02^{\text {ns }}$ & $0.43^{\text {ns }}$ \\
\hline $\mathrm{Tl}$ & 7.67 & 2454.52 & 42.99 \\
\hline $\mathrm{T} 2$ & 7.43 & 2291.72 & 42.10 \\
\hline T3 & 7.37 & 2562.84 & 41.94 \\
\hline T4 & 7.78 & 2300.75 & 43.44 \\
\hline T5 & 7.78 & 2890.42 & 43.65 \\
\hline T6 & 8.27 & 2585.66 & 44.03 \\
\hline Days after transplantation (DAT) ("F") & $81.03^{* *}$ & $119.22^{* *}$ & $14.89^{* *}$ \\
\hline 40 & $2.95 \mathrm{f}$ & $120.52 \mathrm{e}$ & $34.96 \mathrm{~d}$ \\
\hline 68 & $4.78 \mathrm{e}$ & $492.58 \mathrm{e}$ & $40.56 \mathrm{C}$ \\
\hline 124 & $7.07 \mathrm{~d}$ & $1114.88 d$ & $43.32 \mathrm{~b}$ \\
\hline 180 & $9.22 c$ & $2759.68 \mathrm{c}$ & $45.05 \mathrm{~b}$ \\
\hline 236 & $10.56 \mathrm{~b}$ & $4411.03 \mathrm{~b}$ & $44.52 \mathrm{~b}$ \\
\hline 292 & $11.69 \mathrm{a}$ & $6187.21 \mathrm{a}$ & $49.79 a$ \\
\hline Interaction P X DAT ("F") & $0.50^{*}$ & $1.38^{\text {ns }}$ & $0.90^{\text {ns }}$ \\
\hline V.C. (\%) & 23.99 & 42.92 & 14.68 \\
\hline
\end{tabular}

Table 4. Interaction effect of the application of products with physiological action and days after transplantation (DAT) of rose seedlings cv. Carola on the number of leaves.

\begin{tabular}{ccccccc}
\hline \multicolumn{7}{c}{ Number of leaves $^{(\mathrm{a})} / \mathbf{D A T}$} \\
\hline Treatments & $\mathbf{4 0}$ & $\mathbf{6 8}$ & $\mathbf{1 2 4}$ & $\mathbf{1 8 0}$ & $\mathbf{2 3 6}$ & $\mathbf{2 9 2}$ \\
\hline $\mathrm{T} 1$ & $3.00 \mathrm{aC}$ & $4.41 \mathrm{aC}$ & $7.14 \mathrm{aB}$ & $9.62 \mathrm{aA}$ & $10.76 \mathrm{aA}$ & $11.08 \mathrm{aA}$ \\
T2 & $3.04 \mathrm{aC}$ & $4.58 \mathrm{aC}$ & $7.36 \mathrm{aB}$ & $7.91 \mathrm{aB}$ & $9.51 \mathrm{aB}$ & $12.17 \mathrm{aA}$ \\
T3 & $2.91 \mathrm{aC}$ & $4.85 \mathrm{aC}$ & $6.02 \mathrm{aC}$ & $8.58 \mathrm{aB}$ & $9.27 \mathrm{aB}$ & $12.57 \mathrm{aA}$ \\
T4 & $2.91 \mathrm{aC}$ & $4.55 \mathrm{aC}$ & $7.38 \mathrm{aB}$ & $9.52 \mathrm{aA}$ & $10.72 \mathrm{aA}$ & $11.58 \mathrm{aA}$ \\
T5 & $2.90 \mathrm{aC}$ & $5.28 \mathrm{aB}$ & $6.82 \mathrm{aB}$ & $9.85 \mathrm{aA}$ & $10.57 \mathrm{aA}$ & $11.10 \mathrm{aA}$ \\
T6 & $2.95 \mathrm{aC}$ & $5.03 \mathrm{aC}$ & $7.71 \mathrm{aB}$ & $9.83 \mathrm{aA}$ & $12.52 \mathrm{aA}$ & $11.62 \mathrm{aA}$ \\
\hline
\end{tabular}


for $\mathrm{Tl}, \mathrm{T} 4, \mathrm{~T} 5$ and $\mathrm{T} 6$, and after the third pruning (181 DAT) for T2 and T3. Indeed, the prunings received by the plant throughout the cultivation are essential for the formation of a good skeleton and for allowing the production of stems in quantity and quality, according the reported by Hoog (2001). However, the higher effect throughout time for each product might be attributed to the time of action and their mobility in the plant. In this scenario, it is possible to infer that T5 actuated in the physiology of the plant, presenting less time to start its effect on the plants and providing an increase in the number of leaves, important for the formation process of the plants. Furthermore, according to Jabs (2004), there may have occurred the "memory effect" or the effect persistence, even in the absence of the product, responding and standing out to the stress conditions.

In works performed with large crops, such as bean, when utilizing the pyraclostrobin molecule, it was revealed that this molecule presented the best physiological effect, in which, in a lesser period of time, it reached the higher rate of foliar area increase, the best results for the number of pods per plant and, consequently, the best grain yield (Kozlowski et al., 2009). The application of pyraclostrobin provided a higher number of leaves per plant compared to the witness (water) in carrot plants when cultivated in conditions of high fertility of the soil (Colombari et al., 2015). Both cited species are considered annual crops and suffer senescence processes. Sirtoli et al. (2011) attributed these increments to the likely reduction in the ethylene production caused by the usage of pyraclostrobin, causing a delay in the foliar senescence and thus allowing a greater duration of the foliar area.

Concerning the foliar area variable (Table 3) it was observed that even in the absence of statistical difference among the applied products, the higher value was obtained by $\mathrm{T} 5$, with an increment of $17.75 \%, 26.12 \%, 12.52 \%$, $25.63 \%$ and $11.80 \%$ compared to $\mathrm{T} 1, \mathrm{~T} 2, \mathrm{~T} 3, \mathrm{~T} 4$ e T6, respectively. Throughout time, in function of the development and growth of the plants, the appearing of new leaves consequently occasioned an increase in the foliar area variable. The higher and statistically superior foliar area to other dates occurred at 292 DAT. It is worth noting that the higher increase in this variable occurred after the second pruning $(125$ DAT) until 180 DAT, in the order of $147 \%$. After the third and last formation pruning of the cycle, at 181 DAT, the increment was smaller considering the same previous time period (59.8\%); and from 236 DAT until 292 DA there was in increment of $40.2 \%$. This reduction in the foliar area increment is likely due to the fact that the plants started to invest in the production of floral stems, and from 236 DAT the collection of these stems began.

Leaves are important, since they constitute the main photosynthetic organ of plants. The literature indicates that $86 \%$ of rose production depends on the interception of solar radiation and, consequently, in the foliar area and number of leaves (Hoog, 2001). In this aspect, it is necessary to emphasize the importance that in the first months after cultivation, the rose garden must produce foliar mass to store the necessary energy for the budding of the basal branches which will form the skeleton of the plant and, posteriorly, assure the productivity of the stems to be harvested (Gao et al., 2012).

The application of the products also did not statistically affect the total chlorophyll content of the leaves, however, throughout the cultivation, there was a statistical difference. At 40 DAT, the smaller total content of chlorophyll occurred, statistically different of the other dates, in which the plants were still in acclimatization phase. At 68 DAT, there was in increment in the chlorophyll content, probably due to the effect of the manuring, as well as the effect of the applied products. From that date the prunings begun, totalizing three formation prunings, in which the chlorophyll content was statistically similar to the 124, 180 and 236 DAT. At 292 DAT the highest foliar chlorophyll content occurred, statistically superior to the other dates. These higher values throughout time are due to the fact that the plant was in full growth and the nutrient demand suffers variations. The nitrogen, for example, is the most required nutrient by the crop and its demand increases throughout the cycle (Cabrera, 2000), which likely occasioned the increase in the chlorophyll content, since it is a constituent of the chlorophylls and, furthermore, its availability 
might influence in the photosynthetic capacity of the plants (Taiz \& Zeiger, 2011).

For the dry mass values (Table 5) the effect of the interaction of applied products $x$ DAT for dry mass of leaves and flowering branches was observed. For the dry mass of stem there was a significative effect for the DAT; whilst for the dry mass of stem there was a statistical difference for both studied factors.

Table 5. Dry mass of leaves (DML), stem (DMS), flowering branches (DMFB) and total of shoot part (MST) of rose Cv. Carola under application of products with physiological action at 40, 68, 124, 180, 236 and 292 days after transplantation of the seedlings (DAT).

\begin{tabular}{|c|c|c|c|c|}
\hline \multirow{2}{*}{ Variation cause } & DML & DMS & $\mathrm{DMFB}^{(a)}$ & $M S T^{(b)}$ \\
\hline & \multicolumn{4}{|c|}{ g plant $^{-1}$} \\
\hline Products (P) ("F") & $7.51^{* *}$ & $0.95^{\text {ns }}$ & $2.94^{*}$ & $2.12^{*}$ \\
\hline $\mathrm{Tl}$ & $13.11 \mathrm{~b}$ & 22.06 & $1.31 \mathrm{~b}$ & $38.31 \mathrm{~b}$ \\
\hline $\mathrm{T} 2$ & $13.65 b$ & 21.03 & $1.44 \mathrm{~b}$ & $39.06 \mathrm{~b}$ \\
\hline T3 & $16.91 \mathrm{a}$ & 27.84 & $1.54 \mathrm{a}$ & $50.12 a$ \\
\hline T4 & $13.73 b$ & 20.97 & $1.54 \mathrm{a}$ & $40.14 \mathrm{~b}$ \\
\hline T5 & $20.84 a$ & 23.05 & $1.60 a$ & $49.89 \mathrm{a}$ \\
\hline T6 & $20.02 a$ & 19.22 & $1.39 \mathrm{~b}$ & $43.07 \mathrm{~b}$ \\
\hline Days after transplantation (DAT) ("F") & $148.59 * *$ & $65.48^{* *}$ & $926.61^{* *}$ & $173.50^{* *}$ \\
\hline 40 & $0.68 d$ & $0.91 \mathrm{~d}$ & $0.71 \mathrm{~b}$ & $1.59 \mathrm{e}$ \\
\hline 68 & $2.27 \mathrm{~d}$ & $1.64 \mathrm{~d}$ & $0.71 \mathrm{~b}$ & $3.91 \mathrm{e}$ \\
\hline 124 & $8.30 \mathrm{c}$ & $6.69 \mathrm{~d}$ & $0.71 \mathrm{~b}$ & $14.99 \mathrm{~d}$ \\
\hline 180 & $18.54 \mathrm{~b}$ & $19.97 \mathrm{C}$ & $0.71 \mathrm{~b}$ & $38.51 \mathrm{C}$ \\
\hline 236 & $32.51 \mathrm{a}$ & $46.31 \mathrm{~b}$ & $0.71 \mathrm{~b}$ & $78.82 \mathrm{~b}$ \\
\hline 292 & $35.96 a$ & $58.62 a$ & $5.29 a$ & $122.77 a$ \\
\hline Interaction P X DAT ("F") & $2.48^{* *}$ & $0.86^{\text {ns }}$ & $2.94^{* *}$ & $1.36^{\mathrm{ns}}$ \\
\hline V.C. (\%) & 37.35 & 66.66 & 20.47 & 41.41 \\
\hline
\end{tabular}

Considering the interaction effect on the

dry mass of leaves (Table 6) it was observed that among the applied products, until 124 DAT, they were all statistically similar among each other. From 180 days the differences among products appeared, with T5 standing out with statistical superiority compared to the other treatments, which were similar among each other. At 236 DAT, T5 and T6 were statistically similar between each other and superior to the remaining; $\mathrm{T} 2$ and T3 also did not differ between each other, such as T1 and T4. On the last date, at 292 DAT, T3, T5 and $\mathrm{T} 6$ treatments were statistically similar among each other and superior to the remaining. Comparing each product with the dates it was noted that the results are variable, with different behaviors, which might be related to the time of action of each product. It is worth noting that the highest obtained values, although without statistical difference among each other, on $\mathrm{Tl}$, occurred from 180 to 292 DAT, and for T2, T5 and T6, between 236 and 292 DAT. For the T3 and T4 treatments, at 292 DAT, the highest production of dry mass of leaves occurred, statistically significative compared to the remaining dates.

As to the dry mass of flowering branches (Table 6), only at 292 DAT there was a statistical difference among the applied products, once that until 236 DAT there were no stems with flowers that could be harvested. The T3, T4 and T5 treatments were statistically equal among each other and superior to the remaining treatments. As to the evaluation epochs at 292 DAT for all treatments a higher dry mass of flowering branches was observed compared to the previous dates. In this case, it stands out that the flowering stems with enough quality to be harvested were defined from 237 DAT, being fit for harvest in this interval until 292 DAT.

For the dry mass of stem (Table 5) there was only a significative effect of the time, being the highest values observed at 292 DAT. It was noted that in the three first periods $(40,68$ and 124 DAT) there was no increase in the dry mass of stem. It is probably due to the higher investing in leaf production, important organs in the substratum formation for the plant development. Regarding the total dry mass, T3 and T5 treatments stand 
out, which were statistically similar between each other and superior to the remaining treatments. Considering the factor days after transplantation, at 292 DAT the greater accumulation of total dry matter occurred, significantly superior to the remaining dates, which was expected.

Table 6. Interaction effect of the application of products with physiological action and days after transplantation (DAT) of rose seedlings cv. Carola on dry mass of leaves and dry mass of flowering branches.

\begin{tabular}{|c|c|c|c|c|c|c|}
\hline \multicolumn{7}{|c|}{ Dry mass of leaves (g plant ${ }^{-1}$ ) / DAT } \\
\hline Treatments & 40 & 68 & 124 & 180 & 236 & 292 \\
\hline T1 & $0.64 \mathrm{aC}$ & $1.37 \mathrm{aC}$ & $11.31 \mathrm{aB}$ & $16.85 \mathrm{bA}$ & $24.57 \mathrm{cA}$ & $23.93 \mathrm{bA}$ \\
\hline $\mathrm{T} 2$ & $0.73 \mathrm{aC}$ & $1.66 \mathrm{aC}$ & $6.35 \mathrm{aB}$ & $12.22 \mathrm{bB}$ & $28.58 \mathrm{bA}$ & $32.40 \mathrm{bA}$ \\
\hline T3 & $0.68 \mathrm{aD}$ & $3.74 \mathrm{aD}$ & $3.68 \mathrm{aD}$ & $17.45 \mathrm{bC}$ & $33.39 \mathrm{bB}$ & $42.51 \mathrm{aA}$ \\
\hline T4 & $0.64 \mathrm{aC}$ & $2.81 \mathrm{aC}$ & $8.70 \mathrm{aC}$ & $17.61 \mathrm{bB}$ & $21.43 \mathrm{CB}$ & $31.21 \mathrm{bA}$ \\
\hline T5 & $0.73 \mathrm{ac}$ & $2.03 \mathrm{aC}$ & $9.26 \mathrm{aC}$ & $27.05 \mathrm{aB}$ & $42.21 \mathrm{aA}$ & $43.79 \mathrm{aA}$ \\
\hline T6 & $0.69 \mathrm{aD}$ & $2.03 \mathrm{aD}$ & $10.54 \mathrm{aC}$ & $20.06 \mathrm{bB}$ & $44.91 \mathrm{aA}$ & $41.91 \mathrm{aA}$ \\
\hline \multicolumn{7}{|c|}{ Dry mass of flowering branch $\left(\text { g plant }^{-1}\right)^{\text {(a) }} /$ DAT } \\
\hline Treatments & 40 & 68 & 124 & 180 & 236 & 292 \\
\hline $\mathrm{T1}$ & $0.71 \mathrm{aB}$ & $0.71 \mathrm{aB}$ & $0.71 \mathrm{aB}$ & $0.71 \mathrm{aB}$ & $0.71 \mathrm{aB}$ & $4.38 \mathrm{cA}$ \\
\hline T2 & $0.71 \mathrm{aB}$ & $0.71 \mathrm{aB}$ & $0.71 \mathrm{aB}$ & $0.71 \mathrm{aB}$ & $0.71 \mathrm{aB}$ & $5.12 \mathrm{bA}$ \\
\hline T3 & $0.71 \mathrm{aB}$ & $0.71 \mathrm{aB}$ & $0.71 \mathrm{aB}$ & $0.71 \mathrm{aB}$ & $0.71 \mathrm{aB}$ & $5.69 \mathrm{aA}$ \\
\hline T4 & $0.71 \mathrm{aB}$ & $0.71 \mathrm{aB}$ & $0.71 \mathrm{aB}$ & $0.71 \mathrm{aB}$ & $0.71 \mathrm{aB}$ & $5.71 \mathrm{aA}$ \\
\hline T5 & $0.71 \mathrm{aB}$ & $0.71 \mathrm{aB}$ & $0.71 \mathrm{aB}$ & $0.71 \mathrm{aB}$ & $0.71 \mathrm{aB}$ & $6.04 \mathrm{aA}$ \\
\hline $\mathrm{T} 6$ & $0.71 \mathrm{aB}$ & $0.71 \mathrm{aB}$ & $0.71 \mathrm{aB}$ & $0.71 \mathrm{aB}$ & $0.71 \mathrm{aB}$ & $4.79 \mathrm{bA}$ \\
\hline
\end{tabular}

Corroborating the results obtained in the rose cultivation, though morphologically distinct from the following mentioned species, there are reports for banana trees treated with strobilurins, especially pyraclostrobin, which evidence a higher dry mass index of the shoot part when compared with not treated plants (Lima et al., 2012). These treated plants did also present a greater height, larger pseudostem diameter and higher foliar area.

Although there was no significative result among applied products for the production of floral stems (Table 7) it was observed that T5 (Fluxapyroxad + Pyraclostrobin) follower by T3 (Pyraclostrobin) were the treatments with higher values for the production of floral stems. In a work performed with $\mathrm{cv}$. Carola, in a density of 3.3 plants per $\mathrm{m}^{-2}$, an average monthly yield of 1.5 floral stems per plant was observed, and an average yield of 5.0 floral stems per $\mathrm{m}^{-2}$ (Bastos et al., 2017). Thus, even considering that the production in the present work was late and inferior to the values obtained in the cited work, considering mainly the high temperatures during the cultivation, it is worth noting that the plants did get into production in a region in which there is no tradition of rose cultivation.

Analyzing the biomass partition throughout the cultivation, it was observed that at 40 DAT an investment of more than $50 \%$ in

Table 7. Production of floral stems of rose cv. Carola under application of products with physiological action at 292 days after transplantation of the seedlings (DAT).

\begin{tabular}{cc}
\hline \multicolumn{2}{c}{ Production (stems plant"-1) } \\
\hline Variation source & 292 DAT \\
Blocks ("F") & $2.15^{\text {ns }}$ \\
Treatments ("F") & $1.60 \mathrm{~ns}$ \\
T1 & $8.8 \mathrm{a}$ \\
T2 & $7.0 \mathrm{a}$ \\
T3 & $9.3 \mathrm{a}$ \\
T4 & $6.8 \mathrm{a}$ \\
T5 & $10.5 \mathrm{a}$ \\
T6 & $7.0 \mathrm{a}$ \\
VC (\%) & 29.47 \\
\hline ns = not significative; $V . C .=$ variation coefficient. Averages followed by the same letter on the column do not differ \\
among each other by the Scott-Knott test. Treatments= T1: witness (water application T2: boscalid; T3: pyraclostrobin; \\
T4: mixture of boscalid + pyraclostrobin; T5: ready mixture of fluxapyroxad+ pyraclostrobin; T6: ready mixture of vegetal \\
regulators: kinetin + gibberellic acid + 4-indol-3-ylbutyric acid.
\end{tabular}


biomass production of stems compared to leaves in all treatments with the applied products occurs (Figure 2A). At 68 DAT, T3, T4, T5 and T6 treatments stood out in the production of dry mass of leaves (Figure 2B), partitioning, respectively, 59\%, 66\%, $57 \%$ and $57 \%$ of the dry mass for leaves. At 124 DAT, T1, T4, T5 and T6 treatments maintained the allocation of dry mass for the leaves while $\mathrm{T} 2$ and T3 were practically equalized (Figure $2 \mathrm{C}$ ). It is worth noting that at 69 DAT the first pruning was performed, to accumulate reserves and generate healthy and quality buddings. At 180 DAT, only T5 and T6 kept superior in the biomass partition for leaves (Figure 2D), even after the second pruning performed at 125 DAT. After the third and last pruning, performed at 181 DAT, it was noted that all treatments at 236 DAT invested more in stem production (Figure 2E). Continuing in this perspective, at 292 DAT, the biomass allocation for stem was superior compared to leaves and flowering branches (Figure 2F). However, it was noted that $\mathrm{T} 5$ and $\mathrm{T} 6$ were the treatments that invested $63 \%$ and $61 \%$, respectively, on mass partition for leaves and flowering branches. In this perspective, biomass allocation for stem was of $37 \%$ and $39 \%$, respectively. Differently from the remaining treatments, in which the biomass allocation for stem was in a range of $45 \%$ to $52 \%$.
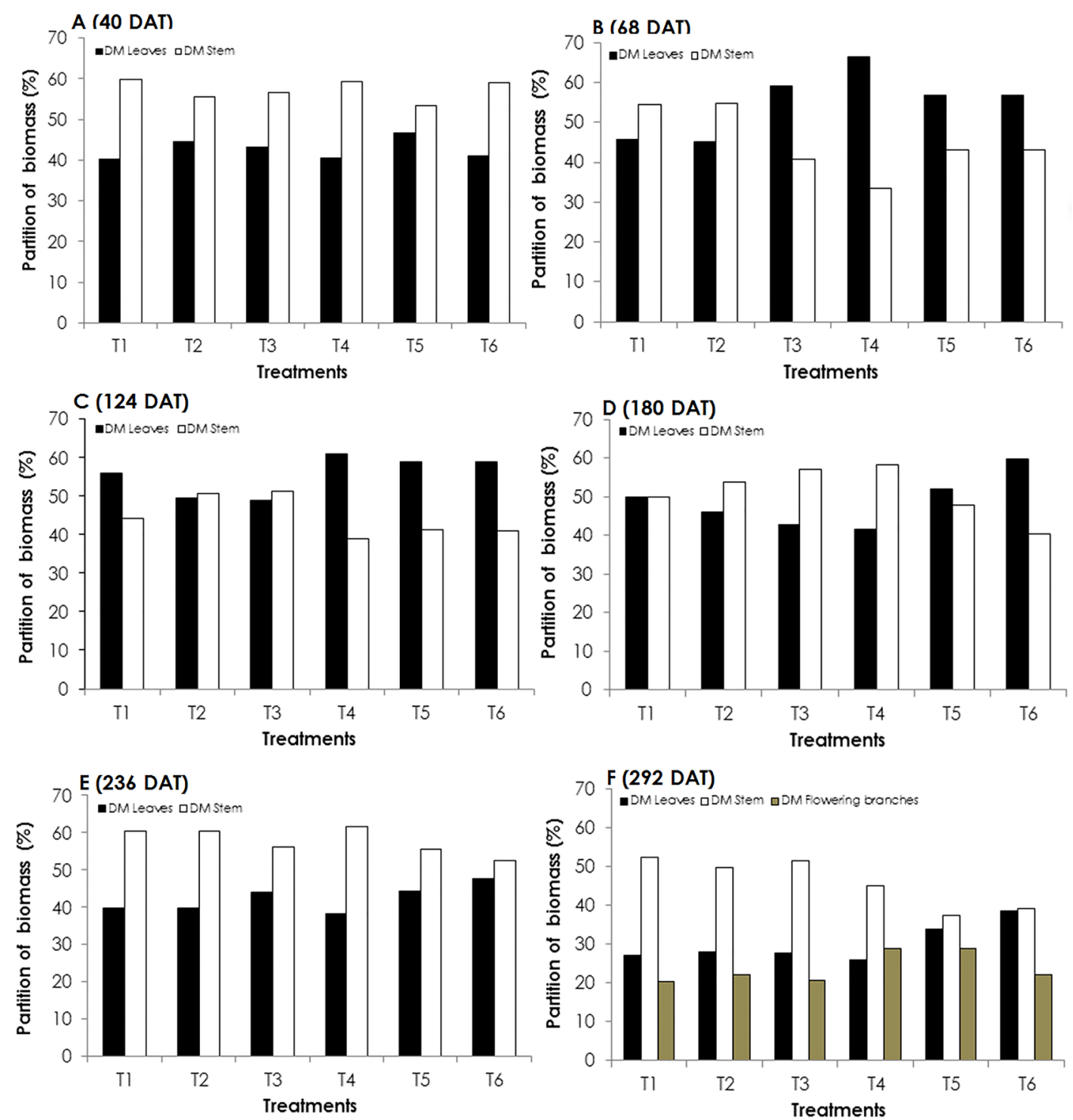

Figure 2. Partition of dry biomass of leaves (DM Leaves), stem (DM Stem) and flowering branches (DM Flowering branches) at 40 (A), 68 (B), 124 (C), 180 (D), 236 (E) and 292 (F) days after transplantation of the seedlings (DAT) in function of the products with physiological action applied during the growth of cut roses cv. Carola. Treatments= T1: witness (water application T2: boscalid; T3: pyraclostrobin; T4: mixture of boscalid + pyraclostrobin; T5: ready mixture of fluxapyroxad+ pyraclostrobin; T6: ready mixture of vegetal regulators: kinetin + gibberellic acid + 4-indol-3-ylbutyric acid. 
These results corroborate the affirmations of Hoog (2001). The rose plants invests in the process of foliar area development, but there is, initially, the need for formation of the plant skeleton, that is the stem, which, alongside the leaves, exercise a vital importance, since they store reserves utilized in the plant growth. According to the same author, the thicker the branch the better the strength of the buddings. It is supposed that the greater biomass of branches allied to a higher diameter produces a stem of better quality for harvesting. The predominance of the stems as reserve receptors was evident, promoting healthier and quality new buddings.

The results agree with the reported by Fagan et al. (2010), when they affirm that beyond the fungicide effect, Strobilurin based products favor the accumulation of dry phytomass and, consequently, the higher availability of photoassimilateds might become a promoter of higher productivities. This effect, according to Balba (2007) is associated to the modus operandi of this molecule, which actuates in cellular respiration, on the mitochondria, in the bcl cytochrome, temporarily interfering in the electron transport and, as a consequence, it generates a better utilization of $\mathrm{CO}_{2}$, reducing energy spending, resulting in a greater carbohydrate accumulation (increase of net photosynthesis), increment of the nitrate reductase activity, "green effect" due to the higher content of chlorophyll and decrease of stress associated with the reduction of the ethylene synthesis, thus allowing a greater duration of the leaf area. Still, according to Kanungo \& Joshi (2014), its utilization might promote, throughout the crop cycle, a higher tolerance of the plant to abiotic stresses due to its action in the abscisic acid metabolism and antioxidant enzymes.

During the rose cultivation, it was possible to verify that there was a large temperature variation in the interior of the shade house. The average temperature of the day, minimal average and maximum average variated from 24 to $31^{\circ} \mathrm{C}, 17$ to $23^{\circ} \mathrm{C}$ and 31 to $42^{\circ} \mathrm{C}$, respectively (Figure 1), while the ideal temperature for the adequate growth and development of the crop lies in a range of 18 to $25^{\circ} \mathrm{C}$ and also that, preferably, daily temperature must be within 23 to $25^{\circ} \mathrm{C}$, and the nocturnal temperature within 15 to $18^{\circ} \mathrm{C}$ (Barbosa et al., 2005). The lowest registered temperatures occurred throughout late night and the highest ones near to 13h:00 and 14h:00.

Considering this range, it is notable that the registered temperatures were much higher than those demanded by the crop, and that they probably occasioned stresses, disturbing the adequate development of the plants since, according to Greyvenstein et al. (2014), excessively high or low temperatures might cause irreversible damages to growth and development of the plants and, consequently, they negatively affect the longevity and the quality of the cut roses stems. Jiao \& Grodzinski (1998) reported that the exportation rate of carbohydrates in the expanded leaves of the stems destined for flowering was reduced in $80 \%$ under high temperature $\left(40^{\circ} \mathrm{C}\right)$, suggesting that the temperature influences in the exportation and assimilated partitioning, what might probably have occurred in the present work when observing biomass allocation, mainly from 180 DAT, when the registered temperatures where over the tolerated temperatures by the crop (Figure 1), investing more in the stem.

However, $\mathrm{T} 5$ and $\mathrm{T} 6$ treatments managed to equilibrate the biomass partition (Figure 2F). It is possible to infer that T6, composed by kinetin + gibberellic acid + 4-indol-3-ylbutyric acid, probably actuated in a synergistic way, in which the combination of effect for each of these vegetal regulators promoted a development of the shoot part in a more equilibrated way, as also reported by Cato at al. (2013). It was noted that in stress conditions, such as high temperatures in the course of the experiment, vegetal hormones might aid in defense mechanisms of the plants and promote growth and development. The efficiency of the application of vegetal regulators might depend of the development stage, dosage, age or general biological condition of the plant (Taiz \&Zeiger, 2011). For example, the gibberellin absorption by the leaves might by stimulated by temperatures inferior to $32^{\circ} \mathrm{C}$ and absence of biotic or abiotic stress (Yamaguchi, 2008), and in the course of the experiment temperatures over $31^{\circ} \mathrm{C}$ were registered with a certain constancy (Figure 1). Concerning 
cytokinin, one of the positive effects on the plants might have been the induction of leaves with a more intense green coloring. Although there has been no significative difference among applied products, it was the T6 which presented the higher content of chlorophyll (Table 2). According with Taiz \& Zeiger (2011), the cytokinins might retard senescence (aging) of the leaves, and the application of cytokinin might attenuate the effects of this physiological process.

Based in the results of this work it was visibly observed that there were limitations in the development of the crop; however, the data showed that the application of the treatments which utilize pyraclostrobin allow the production of floral stems, as well as the treatment with the mixture of vegetal regulators also synergistically actuated over the rose crop. It is supposed that throughout the crop cycle a regulation in the hormonal level occurred to overwhelm the stress and to alleviate the oxidative stress of the plants, such as suggested by Kanungo \& Joshi (2014) when they used strobilurins, and by Cato (2013), when utilizing the vegetal regulators.

\section{Conclusions}

Based on the crop conditions, it is possible to conclude that the application of products of the strobilurins chemical group and the mixture of vegetal regulators are promising for rose crop in the Brazilian semiarid. However, the performing of new essays is suggested for improvements in the productive system for the cultivation in the semiarid region.

\section{Acknowledgments}

To the FAPEPI (Fundação de Amparo à Pesquisa do Estado do Piauí) for the concession of the first author's scholarship and to FACEPE (Fundação de Amparo à Ciência e Tecnologia do Estado de Pernambuco) and CNPq (Conselho Nacional de Desenvolvimento Científico e Tecnológico) for the aid in the research project (Process no. APQ-1062-5.01/14).

\section{References}

Alvares, C.A., Stape, J.L., Sentelhas, P.C., Gonçalves, J.L.M., Sparovek, G. 2014. Köppen's climate classification map for Brazil. Meteorologische Zeitschrift, 22: 711-728.

Avenot, H.F., Michailides, T.J. 2010. Progress in understanding molecular mechanisms and evolution of resistance to succinate dehydrogenase inhibiting (SDH) fungicides in phytopathogeni fungi. Crop protection, 29: p.643-651.

Balba, H. 2007. Review of strobilurin fungicide chemicals. Journal of Environmental Science and Health, 42: 441-451.

Barbosa, J.G., Grossi, J.A.S., Pivetta, K.F.L., Finger, F.L., Santos, J.M. 2005. Cultivo de rosas. Informe Agropecuário, 26: 20-29.

Bartlett, D.W., Clough, J.C., Godfrey, C.R.A., Godwin, J.R., Hall, A.A., Heaney, S.P., Steve, J. 2001. Understanding the strobilurin fungicides. Pesticide Outlook, 12: 143-146.

Bastos, F.E.A., Allebrandt, R., Lerin, S., Kretzschmar, A.A., Rufato, L. 2017. Planting density on roses cultivars 'Avalanche' and 'Carola' in Lages-SC. Ornamental Horticulture, 23: 58-62.

Cabrera, R.I. 2000. Evaluating yield and quality of roses with respect to nitrogen fertilization and leaf tissue nitrogen status. Acta Horticulturae, 51 1:133141.

Cato, S.C., Macedo, W.R., Peres, L.E.P., Castro, P.R.C. 2013. Sinergism among auxins, gibberellins and cytokinins in tomato cv. Micro-Tom. Horticultura Brasileira, 31: 549-553.

Cavalcanti, F.J.A. 2008. Recomendações de adubação para o Estado de Pernambuco: segunda aproximação. IPA, Recife, Brasil. 212p.

Colombari, L.F., Baldini, L.F.G., Baldini, V., Cardoso, A.I.I., Goto, R. 2015. Efeito fisiológico de fungicidas sistêmicos em parâmetros agronómicos da cenoura. Revista de Ciências Agrárias, 38: 366-371

Embrapa. Empresa Brasileira de Pesquisa Agropecuária. 2013. Sistema brasileiro de classificação de solos. Embrapa, Brasília, Brasil. $306 \mathrm{p}$.

Fagan, E.B., Dourado Neto, D., Vivian, R., Franco, R.B., Yeda, M.P., Massignan, L.F., Oliveira, R.F., Martins, K.V. 2010. Efeito da aplicação de piraclostrobina na taxa fotossintética, respiração, atividade da enzima nitrato redutase e produtividade de grãos de soja. Bragantia, 69: 771-777.

Gao, M.G., Van Der Heijden, J., Vos, B.A., Eveleens, L.F.M. 2012. Estimation of leaf area for large scale phenotyping and modeling of rose genotypes. Scientia Horticulturae, 138: 227-234.

Greyvenstein, O., Pemberton, B., Starman, T., Niu, G., Byrne, D. 2014. Effect of two-week high- 
temperature treatment on flower quality and abscission of Rosa L. 'Belinda's Dream' and 'Radrazz' (KnockOut ${ }^{\circledR}$ ) under controlled growing environments. HortScience, 49: 701-705.

Hashemabadi, D., Zarchini, M. 2010. Yield and quality management of rose (Rosa hybridacv. Poison) with plant growth regulators. Plant Omics Journal, 3: 167-171.

Hoog, J. 2001. Effects of plant density, harvest methods and bending of branches on the production and quality of roses. Acta Horticulturae, 547: 311-317.

Jabs, T. 2004. Can strobilurins still deliver? Crop protection, 17: 19-20.

Jiao, J., Grodzinski, B. 1998. Environmental influences on photosynthesis and carbon export in greenhouse roses during development of the flowering shoot. Journal of the American Society for Horticultural Science 123: 1081-1088.

Kanungo, M., Joshi, J. 2014. Impact of pyraclostrobin (F-500) on crop plants. Plant Science Today, 3: 174-178.

Kozlowski, L.A., Simões, D.F.M., Souza, C.D., Trento, M. 2009. Efeito fisiológico de estrobilurinas $F 500^{\circledR}$ no crescimento e rendimento do feijoeiro. Revista Acadêmica Ciência Agrária e Ambiental, 7: 41 54.

Lima, J.D., Moraes, W.S., Silva, S.H.M.G. 2012. Respostas fisiológicas em mudas de bananeira tratadas com estrobilurinas. Semina: Ciências Agrárias, 33: 77-86.

Oliveira, E.C., Carvalho, J.A., Almeida, E.F.A., Rezende, F.C., Santos, B.G., Mimura, S.N. 2014. Evapotranspiração da roseira cultivada em ambiente protegido. Revista Brasileira de Engenharia Agrícola e Ambiental, 18: 314-321.

Ramos, A.R.P., Amaro, A.C.E., Macedo, A.C., Souza, E.R., Rodrigues, J.D., Ono, E.O. 2015. Acúmulo de carboidratos no desenvolvimento de tomateiro tratado com produtos químicos. Semina: Ciências Agrárias, 36, 705-718.

Rigueira, M. Floricultura de Minas Gerais avança em desenvolvimento tecnológico. $2015 . \quad$ https://www.em.com.br/app/ noticia/agropecuario/2015/11/16/interna_ agropecuario,708231/floricultura-de-minasgerais-avanca-em-desenvolvimentotecnologico.shtml<Acesso em 7 Jul. 2018>

Santos, C.A.C., Peixoto, C.P., Vieira, E.L., Carvalho, E.V., Peixoto, V.A.B. 2012. Ação da interação cinetina, ácido indolbutírico e ácido giberélico no crescimento inicial e florescimento do girassol. Comunicata Scientiae, 3: 310-315.
Silva, F.A.S., Azevedo, C.A.V. 2016. The Assistat Software Version 7.7 and its use in the analysis of experimental data. African Journal of Agricultural Research, 11:3733-3740.

Sirtoli, L.F., Rodrigues, J.D., Goto, R. 2011. Efeito fisiológico do fungicida boscalida na atividade da nitrato redutase e nas características fitotécnicas de pepineiro japonês enxertado e não enxertado. Scientia Agraria Paranaensis, 10: 58-69.

Taiz, L., Zeiger, E. 2011 . Fisiologia vegetal. 5.ed. Artmed, Porto Alegre, Brasil. 690p.

Yamaguchi, S. 2008. Gibberellin metabolism and its regulation. Annual Review of Plant Biology, 59: 225-251. 